\title{
BMC
}

Genomics

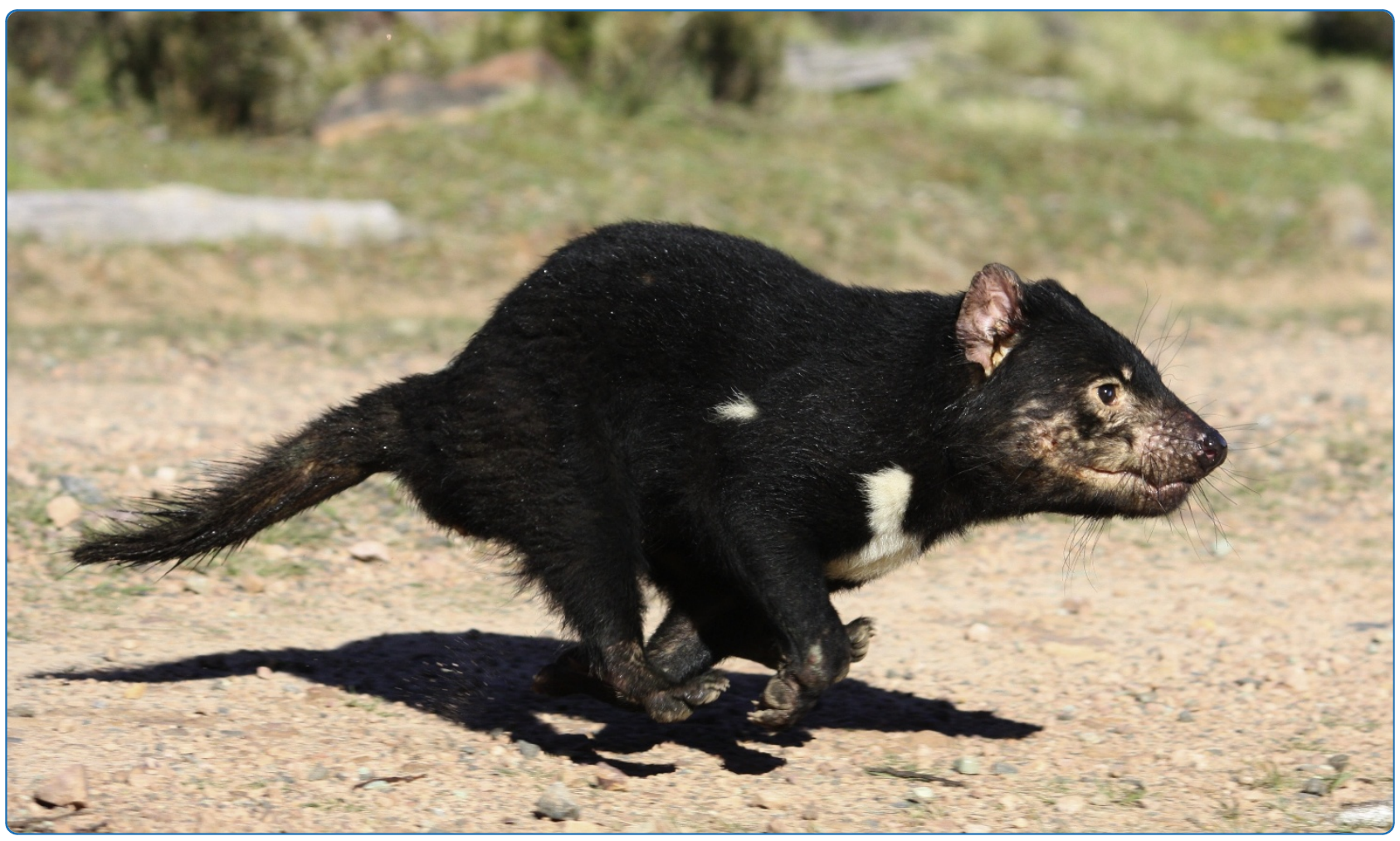

\section{Antigen-presenting genes and genomic copy number variations in the Tasmanian devil MHC}

Cheng et al. 


\title{
Antigen-presenting genes and genomic copy number variations in the Tasmanian devil MHC
}

Yuanyuan Cheng ${ }^{1}$, Andrew Stuart ${ }^{2}$, Katrina Morris $^{1}$, Robyn Taylor ${ }^{3}$, Hannah Siddle ${ }^{1,4}$, Janine Deakin ${ }^{5}$, Menna Jones ${ }^{6}$, Chris T Amemiya ${ }^{2}$ and Katherine Belov ${ }^{1,7^{*}}$

\begin{abstract}
Background: The Tasmanian devil (Sarcophilus harrisii) is currently under threat of extinction due to an unusual fatal contagious cancer called Devil Facial Tumour Disease (DFTD). DFTD is caused by a clonal tumour cell line that is transmitted between unrelated individuals as an allograft without triggering immune rejection due to low levels of Major Histocompatibility Complex (MHC) diversity in Tasmanian devils.
\end{abstract}

Results: Here we report the characterization of the genomic regions encompassing MHC Class I and Class II genes in the Tasmanian devil. Four genomic regions approximately $960 \mathrm{~kb}$ in length were assembled and annotated using BAC contigs and physically mapped to devil Chromosome 4q. 34 genes and pseudogenes were identified, including five Class I and four Class II loci. Interestingly, when two haplotypes from two individuals were compared, three genomic copy number variants with sizes ranging from 1.6 to $17 \mathrm{~kb}$ were observed within the classical Class I gene region. One deletion is particularly important as it turns a Class la gene into a pseudogene in one of the haplotypes. This deletion explains the previously observed variation in the Class I allelic number between individuals. The frequency of this deletion is highest in the northwestern devil population and lowest in southeastern areas.

Conclusions: The third sequenced marsupial MHC provides insights into the evolution of this dynamic genomic region among the diverse marsupial species. The two sequenced devil MHC haplotypes revealed three copy number variations that are likely to significantly affect immune response and suggest that future work should focus on the role of copy number variations in disease susceptibility in this species.

Keywords: MHC, Tasmanian devil, Copy number variation, Devil facial tumour disease

\section{Background}

The Tasmanian devil (Sarcophilus harrisii), an endemic species on the island state of Tasmania, Australia, is the largest remaining carnivorous marsupial in the world [1]. Tasmanian devils ("devils" for short) were found on mainland Australia up to 3,000 to 4,000 years ago [2]. The Tasmanian population has been isolated for over 12,000 years and has undergone two population crashes, due to the current disease epidemic and in around 1900 [3]. As a result, the devil population has an overall low level of genetic diversity [4]. Currently, the devil faces extinction due to the emergence of a fatal contagious cancer - Devil Facial Tumour Disease (DFTD). DFTD

\footnotetext{
* Correspondence: kathy.belov@sydney.edu.au

${ }^{1}$ Faculty of Veterinary Science, University of Sydney, Sydney, NSW, Australia Full list of author information is available at the end of the article
}

was first detected in 1996 at Mt William National Park in the northeast of Tasmania (Figure 1) [3]. Since then, it has rapidly spread south and westwards to over $85 \%$ of the original devil distributional range and caused severe population declines [5]. Research has revealed that DFTD is a clonal cell line, likely of Schwann cell origin, which is transmitted between individuals as an allograft by cellular inoculation (e.g. biting) [6,7]. The "grafted" tumour cells can overcome immunological barriers of the host and adapt in unrelated individuals without inducing immune rejection [8]. The low level of genetic diversity at the Major Histocompatibility Complex (MHC) is believed to have contributed to this process [9].

The MHC is one of the most studied gene regions in vertebrates due to its critical roles in disease resistance and transplantation success. MHC genes have been cloned
C Biomed Central 


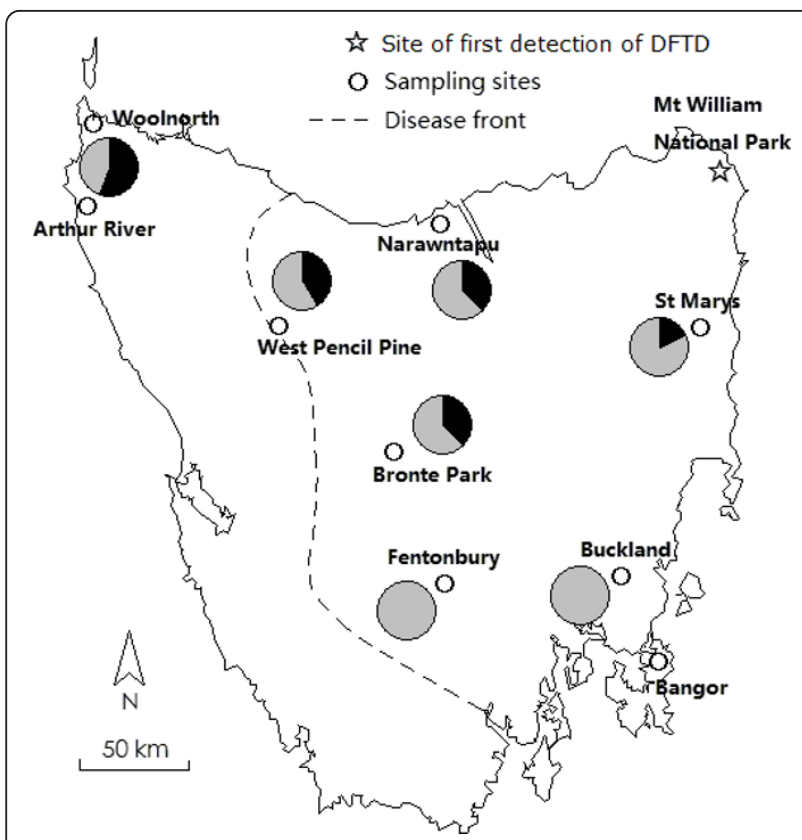

Figure 1 Map of Tasmania showing the sampling sites, location of the first citing of DFTD in 1996 (Mt William), and the present location of the disease front. The black segment in the pie charts shows the proportion of individuals with a deletion at Saha-UA, and the grey segment shows the proportion with intact Saha-UA gene.

and characterized from representatives of all vertebrate classes except agnathan fish [10]. Based on the structure and function of their encoded proteins, MHC genes are grouped into three classes (Class I, II and III) [11]. Class I and II genes are further classified by function as classical and nonclassical, with classical Class I and II genes encoding cell surface molecules that present antigens to $\mathrm{T}$ lymphocytes [11]. The MHC Class I genes are encoded by an $\alpha$ chain, which associates with a $\beta_{2}$-microglobulin chain to become a functional Class I molecule [10]. Classical Class I (Class Ia) molecules are ubiquitously expressed in all tissue types and function in the recognition and destruction of foreign, virus-infected or malignant cells by cytotoxic $\mathrm{T}$ cells [12]. Nonclassical Class I (Class Ib) genes encode Class I-like molecules with varied functions, and generally exhibit lower expression levels, tissue specific expression and/or lower levels of polymorphism [13]. MHC Class II molecules are heterodimers of an $\alpha$ chain and a $\beta$ chain, both of which are encoded in the MHC. They are expressed in cells participating in immune responses such as B lymphocytes, dendritic cells and macrophages. These molecules present antigens derived from intravesicular and extracellular pathogens to CD4 helper T cells, which release signals to trigger antibody production and inflammatory responses that kill the pathogens [14]. In most species, there are multiple closely related MHC gene paralogues, which result from gene duplication events during the evolution of MHC $[15,16]$. Due to selective pressures from ever-changing pathogens in the environment, these antigen-presenting $\mathrm{MHC}$ genes evolve rapidly and are usually highly polymorphic in their peptide-binding regions (exon 2 and 3 of Class I genes; exon 2 of Class II genes), enabling the immune system to recognize an extensive range of pathogenic antigens [17].

Previously, we isolated and characterized devil MHC Class I and Class II $\beta$ chain transcripts [18] and demonstrated low levels of genetic variation in these sequences, especially in eastern Tasmania [19]. In the northwest, a slightly higher level of diversity was observed using single-strand conformation polymorphism (SSCP) typing, while sequencing revealed variation in Class I allelic numbers in different individuals [19], but due to the inherent difficulties in studying the MHC in non-model species, we were not able to rule out null alleles or experimental artefacts. Here we describe the MHC Class I and Class II regions of the Tasmanian devil based on the construction of BAC contigs. We confirm that variation in the number of Class I genes occurs due to a deletion within a Class Ia locus.

\section{Results}

\section{Characterization of MHC regions}

The MHC regions of two individuals were characterized. Cedric, whose parents came from DFTD-free northwestern Tasmania (father from Arthur River and mother from Woolnorth; Figure 1), produced an antibody response when injected with irradiated DFTD cells (Alex Kreiss, University of Tasmania, personal communication) and at the beginning of the project was thought to be a "resistant" animal because he did not develop DFTD following a disease challenge. Since then Cedric has succumbed to DFTD, but remains one of very few animals to be able to mount an antibody response to DFTD. The other individual, named Spirit, was originally from Bangor (Figure 1) and was euthanized in 2008 due to multiple DFTD lesions and metastases to the lungs.

Four genomic regions of approximately $960 \mathrm{~kb}$ in length were assembled and annotated based on ten fully sequenced BAC clones (seven from Cedric and three from Spirit) (Figure 2). 34 genes and pseudogenes were predicted, comprising five Class I genes, four Class II genes, four antigen-processing genes, eight Class III genes and thirteen other genes and pseudogenes. GenBank accession numbers of the BAC clones and coordinates of the predicted genes are shown in Table 1 . The annotated genes were mostly named after their orthologues in the human with the exceptions of MHC Class I and II genes, which were given species-specific names based on the nomenclature proposed by Klein and colleagues [20] and their evolutionary relationships with previously characterized marsupial genes [21,22]. 


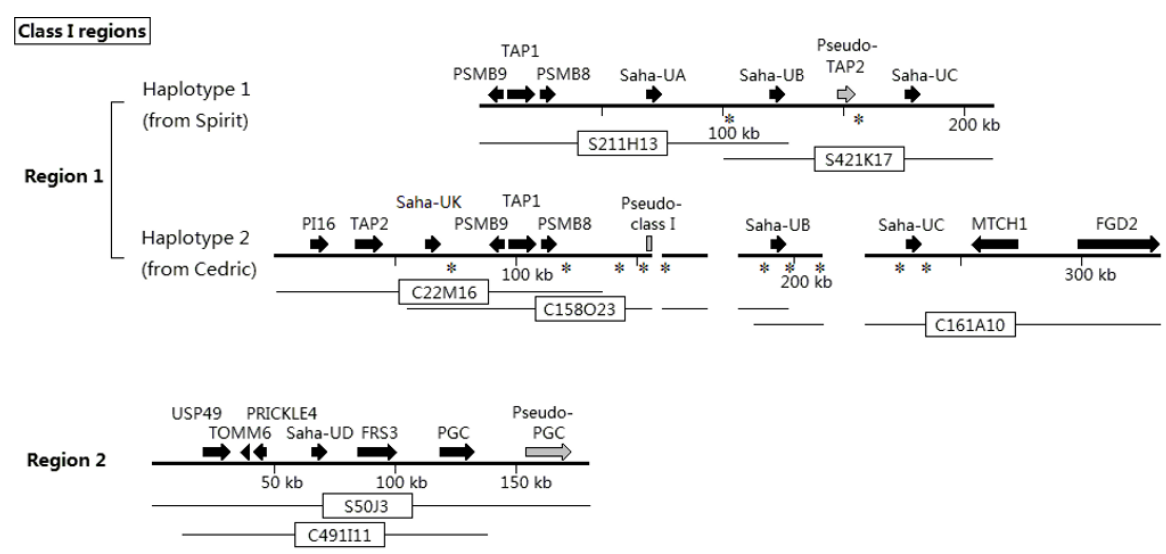

\section{Class II regions}

Region 3

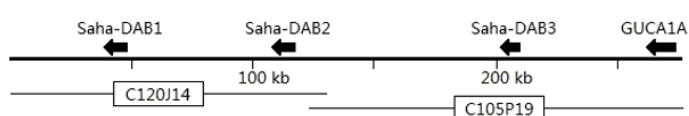

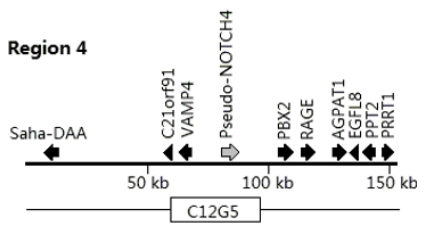

Figure 2 Schematic diagram of Tasmanian devil genomic regions containing MHC genes. Arrows represent annotated genes. BAC clones used for sequence assembly are indicated by lines below the annotation. For the Class I Region 1, alignment of two haplotypes is shown, as significant differences are found between them. The three gaps within haplotype 2 (and BAC C158O23 and C161A10) represent three segments that are not present in this haplotype as compared to haplotype 1. Asterisks indicate positions of 12 putative LINE fragments.

Two of the analysed regions contain Class I genes (Region 1 and 2) and the other two contain Class II (Region 3 and 4) (Figure 2). All four regions were physically mapped to the same area on devil Chromosome 4q, indicating the genomic location of the devil MHC (see Figure 3 for Region 1 and 3, and Additional file 1: Figure S1 for Region 2 and 4). Based on comparisons to the MHC of the grey short-tailed opossum (Monodelphis domestica; herein referred to as "opossum") and the tammar wallaby (Macropus eugenii), Region 3 is likely located between Region 1 and Region 4, which encompasses a suite of well-conserved Class III genes (Figure 4). In Region 2, Class I Saha-UD is flanked by five non-MHC genes USP49, TOMM6, PRICKLE4, FRS3 and PGC, which are found $\sim 12 \mathrm{MB}$ proximal from the $\mathrm{MHC}$ in human and $\sim 16 \mathrm{Mb}$ distal from the MHC in opossum; however, according to FISH mapping result, these genes are closer to the MHC in the devil than in opossum (Additional file 1: Figure S1).

\section{Class I genes}

A total of five Class I genes were identified and named Saha-UA,UB,UC,UD and UK. Except Saha-UD, they are all closely linked (Region 1 in Figure 2) and are localised with PSMB8, PSMB9, TAP1 and TAP2 genes, which are involved in antigen processing and transportation. Saha-UA,UB,UC and $U D$ have evolved from recent gene duplications in the devil lineage (shown in Figure 5) and are not orthologous to Class I genes in the opossum or the tammar wallaby. Saha-UK is orthologous to $M o d o-U K$ in the opossum and Maeu-UK in the tammar wallaby (Figure 5), both of which have been suggested to be nonclassical genes [22,23].

The genomic data allowed us to assign MHC alleles to loci using phylogenetics (Figure 5, Additional file 2: Figure S2). Table 2 describes the alleles sequenced on each of the two haplotypes, and by deduction the alleles found on the un-sequenced haplotypes of Cedric and Spirit. We were able to resolve that previously isolated devil Class I sequence variants $S a h a I * 27$ and 28, 35, 46, and 32 belong to locus Saha-UC, $U A, U B$ and $U D$, respectively. Meanwhile, five novel alleles, named SahaI"86 - 90, were found and assigned to genes. Alleles from Saha-UD, which were previously called group 2 alleles [19], are divergent from other genes and form a discrete phylogenetic clade with $94 \%$ bootstrap support. Saha-UA,UB and $U C$ are closely related, with $U A$ and $U B$ alleles interspersed within the same clade. At nucleotide level, the sequence identity between these three genes is extremely high (>97.7\%), with Saha-UA and $U B$ sharing up to $99 \%$ nucleotide identity in their introns (Table 3).

The sequence $200 \mathrm{bp}$ upstream of the translation start sites was searched for gene regulatory elements, as promoters of MHC Class I genes in mammals are mostly 
Table 1 List of annotated BAC clones.

\begin{tabular}{|c|c|c|c|c|c|}
\hline BAC & Accession & Start & End & Strand & Description \\
\hline \multirow[t]{6}{*}{$\mathrm{C} 22 \mathrm{M} 16$} & FQ482140 & 24985 & 22341 & - & Proteasome subunit, beta type, 8 \\
\hline & & 42720 & 30519 & - & Transporter 1, ATP-binding cassette, sub-family B \\
\hline & & 43296 & 46824 & + & Proteasome subunit, beta type, 9 \\
\hline & & 67202 & 64208 & - & MHC Class I antigen Saha-UK \\
\hline & & 98510 & 88331 & - & Transporter 2, ATP-binding cassette, sub-family B \\
\hline & & 125729 & 116120 & - & Peptidase inhibitor 16-like \\
\hline $\mathrm{C} 158 \mathrm{O} 23$ & FQ482137 & 98067 & 99377 & + & MHC Class I pseudogene \\
\hline \multirow[t]{2}{*}{ C161A10 } & FQ482138 & 97718 & 77164 & - & Mitochondrial carrier homolog 1 \\
\hline & & 122296 & 155379 & + & FYVE, RhoGEF and PH domain containing 2 \\
\hline \multirow[t]{2}{*}{$\mathrm{S} 211 \mathrm{H} 13$} & FQ482144 & 67289 & 70233 & + & MHC Class I antigen Saha-UA \\
\hline & & 118698 & 121642 & + & MHC Class I antigen Saha-UB \\
\hline \multirow[t]{2}{*}{ S421K17 } & FQ482146 & 67403 & 64222 & - & Transporter 2, ATP-binding cassette, sub-family B pseudogene \\
\hline & & 36094 & 33148 & - & MHC Class I antigen Saha-UC \\
\hline \multirow[t]{6}{*}{ C491111 } & FQ482142 & 8066 & 18154 & + & Ubiquitin specific peptidase 49 \\
\hline & & 26396 & 24778 & - & Translocase of outer mitochondrial membrane 6 \\
\hline & & 32637 & 30374 & - & Prickle homolog 4 (Drosophila) \\
\hline & & 53046 & 56295 & + & MHC Class I antigen Saha-UD \\
\hline & & 70180 & 88114 & + & Fibroblast growth factor receptor substrate 3 \\
\hline & & 105924 & 114685 & + & Progastricsin (pepsinogen C) \\
\hline $550 J 3$ & FQ482147 & 154766 & 172999 & + & Progastricsin (pepsinogen C) pseudogene \\
\hline \multirow[t]{2}{*}{ C120J14 } & FQ790236 & 47684 & 38237 & - & MHC Class II DA $\beta$ chain 1 \\
\hline & & 119765 & 110505 & - & MHC Class II DA $\beta$ chain 2 \\
\hline \multirow[t]{2}{*}{ C105P19 } & FQ790235 & 83441 & 74884 & - & MHC Class II DA $\beta$ chain 3 \\
\hline & & 148648 & 135902 & - & Guanylate cyclase activator $1 \mathrm{~A}$ \\
\hline \multirow[t]{10}{*}{ C12G5 } & FQ790241 & 13651 & 9537 & - & MHC Class II DA $\alpha$ chain \\
\hline & & 60582 & 59696 & - & Protein EURL homolog \\
\hline & & 73613 & 71308 & - & Vesicle-associated membrane protein 4-like \\
\hline & & 84027 & 87750 & + & NOTCH4 pseudogene \\
\hline & & 108416 & 112090 & + & Pre-B-cell leukemia homeobox 2 \\
\hline & & 114221 & 117186 & + & Advanced glycosylation end product-specific receptor \\
\hline & & 127655 & 131100 & + & 1-acylglycerol-3-phosphate O-acyltransferase 1 \\
\hline & & 135753 & 133198 & - & Epidermal growth factor-like protein 8 \\
\hline & & 141212 & 138220 & - & Palmitoyl-protein thioesterase 2 \\
\hline & & 148877 & 150447 & + & Proline-rich transmembrane protein 1 \\
\hline
\end{tabular}

Genes in the BAC overlapping regions are only shown once. Letters C and S in BAC clone names indicate Cedric's and Spirit's library, respectively

contained within this range [24]. In Saha-UA,UB and $U C$, this region is highly similar, with only one single nucleotide variation in the TATA sites. Putative sites of an enhancer $\mathrm{A}$, an interferon stimulated response element (ISRE), the S-X-Y motifs, CAAT and TATA boxes were identified (Figure 6). Saha-UD was not included in the alignment in Figure 6 due to low sequence identity. Compared to Saha-UA,UB and $U C$, regulatory elements including enhancers, ISRE, $\mathrm{S}$ and $\mathrm{X}$ motifs are not conserved at this locus, which may indicate different expression or function of this gene.

\section{Comparison of two MHC class I haplotypes}

The MHC region containing the Class Ia genes in Cedric and Spirit (Region 1 in Figure 2) contains three indels. Spirit's haplotype has an intact Saha-UA gene, whereas Cedric's has a deletion $(\sim 1646 \mathrm{bp}$ in size $)$ that results in the loss of a large portion (from exon 2 to intron 5) of Saha-UA and renders it a pseudogene. Furthermore, Cedric's haplotype also lacks two other long segments that are present in Spirit's, one $(\sim 12230$ bp) lying between the pseudogene and Saha-UB, and the other ( 16970 bp) between Saha-UB and Saha-UC. 


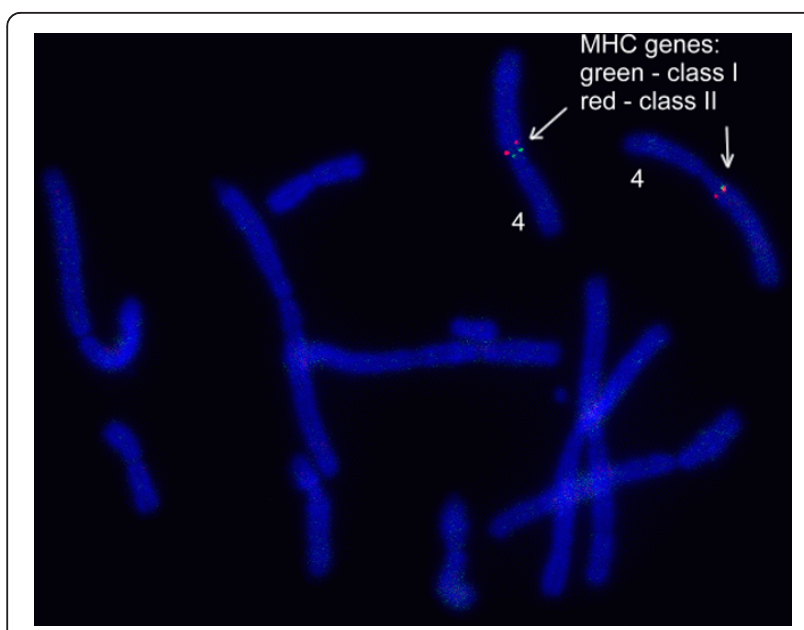

Figure 3 FISH image showing genomic locations of Tasmanian devil MHC Class I and II genes.

Further investigation on this genomic region revealed 12 putative Long INterspersed Element (LINE) segments interspersing the MHC genes (Figure 2), nine of which closely flank (within $2 \mathrm{~kb}$ ) the indels and Saha-UA,UB and $U C$. Two of the putative LINEs are located inside the indels and only found in Spirit's haplotype.

A PCR test was developed to detect the presence or absence of the deletion in Saha-UA in devils. Haplotypes without the deletion generate a single band of 1917 bp in size, which contains amplicons from Saha$U A, U B$ and $U C$ genes. A second band (271 bp) is generated when a haplotype contains the deletion in Saha$U A$, representing an amplicon from only the pseudogene, which has arisen due to the deletion (Figure 7).

\section{Population study}

The frequency of the Saha-UA deletion was assessed in samples from seven geographic areas across Tasmania (see pie charts in Figure 1). 72 individuals were investigated: 25 from DFTD-affected areas in eastern Tasmania (five from each of St Marys, Narawntapu, Bronte Park, Buckland and Fentonbury); 12 from West Pencil Pine, an area on the disease front; and 35 from the DFTDfree northwestern coast region. The deletion is most prevalent in the northwest (found in $54.8 \%$ of tested individuals), followed by West Pencil Pine (41.7\%), Bronte Park (40\%), Narawntapu (40\%) and St Marys (20\%). None of individuals from Fentonbury and Buckland contained the deletion.

\section{Class II genes}

Four Class II genes were identified, all belonging to the marsupial Class II $D A$ gene family. Previously isolated $\mathrm{DAB}$ transcripts were aligned against the three $\beta$ chain paralogues and $100 \%$ match was found between transcripts SahaDAB*01 [GenBank:EF591102], SahaDAB*03 [GenBank:EF591104] and SahaDAB*05 [GenBank: EF591105] and genes Saha-DAB1,DAB2 and DAB3, respectively. Sequence comparison of these three genes is shown in Table 4. Saha-DAB1 and DAB2 share high nucleotide identity in both exons $(96.9 \%)$ and introns (95.7\%). They are both similar to Saha-DAB3 in exon sequences, but differ from it significantly in the introns due to multiple deletions/insertions of nucleotide fragments. In the 5' untranslated region, putative sites of S-X-Y motifs are identified in both $\alpha$ and $\beta$ chain genes, though TATA and CAAT elements are not found in these genes (Figure 8).

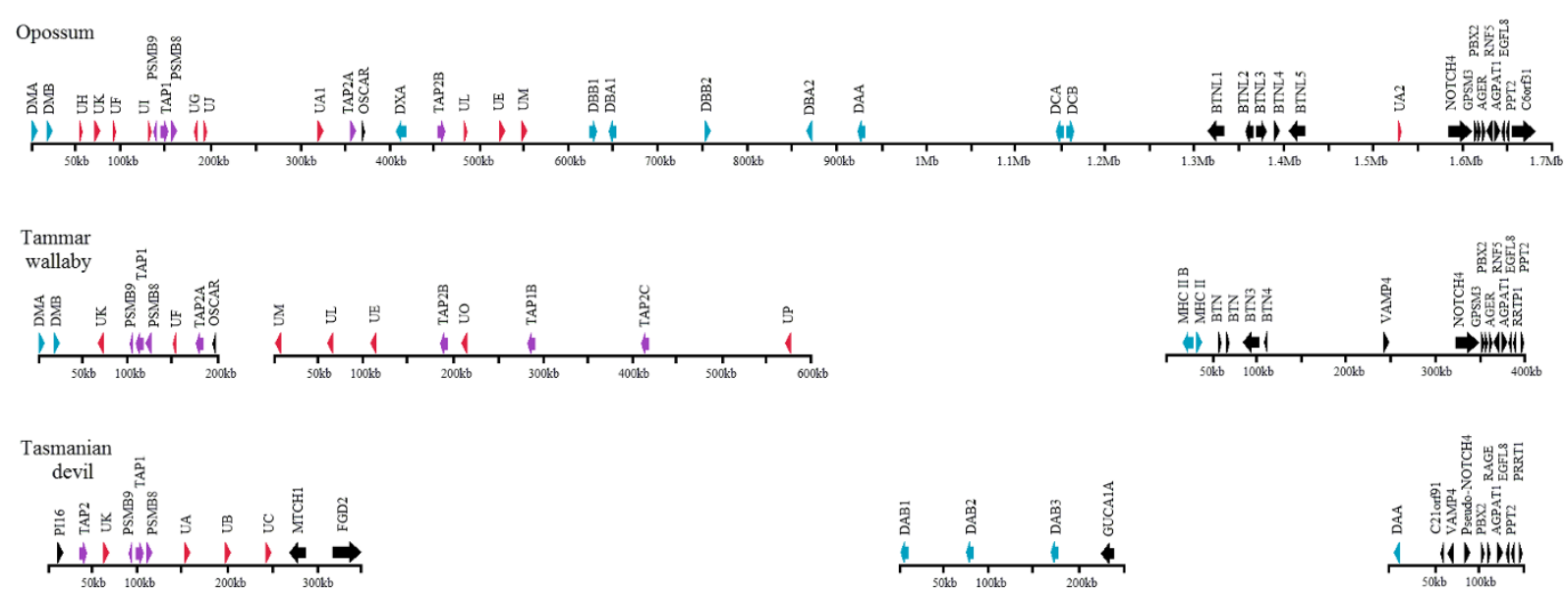

Figure 4 Comparison of MHC regions containing Class I or II genes between Tasmanian devil, grey short-tailed opossum [21]and tammar wallaby [35]. Class I, II and antigen-processing genes are represented with red, blue and purple arrows, respectively. Class II regions of tammar wallaby are not shown due to high complexity. 


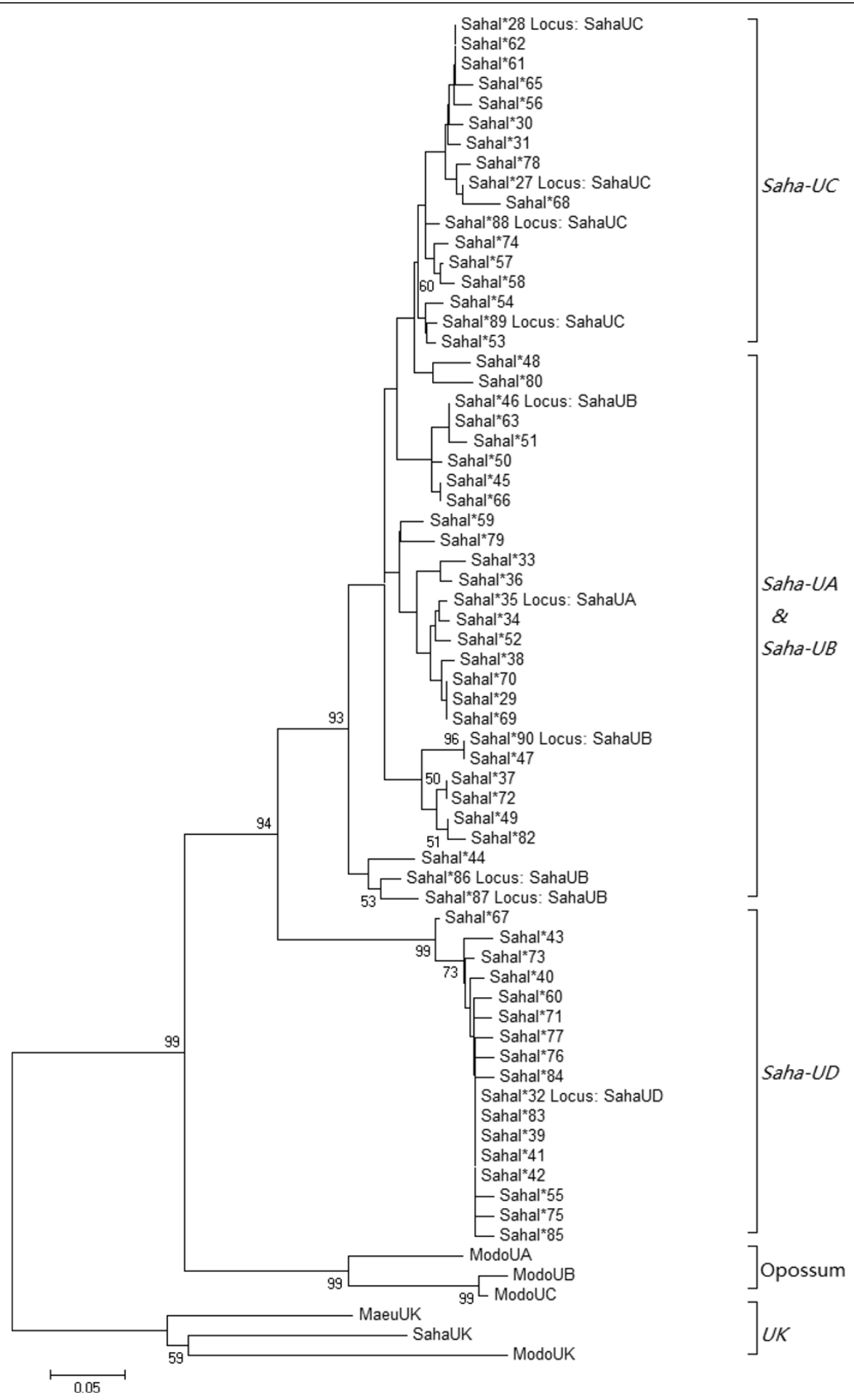

Figure 5 Phylogenetic analysis of Tasmanian devil MHC Class I sequences variants. The phylogenetic relationship was inferred using the Neighbour-Joining method [46]. The percentage of replicate trees in which the associated sequences clustered together in the bootstrap test $(1,000$ replicates) are displayed next to the branches, indicating the level of reliability of the phylogeny [47]. Bootstrap frequencies lower than 50\% are not shown. Phylogenetic analysis was conducted in MEGA5 [45]. Modo-UK [GenBank:EU886686] and Maeu-UK [GenBank:CU463018] are orthologous UK genes in the grey short-tailed opossum and tammar wallaby. Modo-UA [GenBank:DQ067089], UB [GenBank:NM_001079820] and UC [GenBank:NM_001079819] are Class I genes in the opossum. 
Table 2 MHC Class I haplotypes of two model Tasmanian devils - Cedric and Spirit

\begin{tabular}{|c|c|c|c|c|}
\hline \multirow{2}{*}{$\begin{array}{l}\text { Class la } \\
\text { loci }\end{array}$} & \multicolumn{2}{|c|}{ Cedric's haplotypes } & \multicolumn{2}{|c|}{ Spirit's haplotypes } \\
\hline & $\begin{array}{c}\text { a (BAC } \\
\text { sequenced) }\end{array}$ & $b$ & $\begin{array}{c}\text { a (BAC } \\
\text { sequenced) }\end{array}$ & $b$ \\
\hline Saha-UA & - & - & Sahal*35 & Sahal*35 \\
\hline Saha-UB & Sahal*86 & Sahal*87 & Sahal*46 & Sahal ${ }^{*} 90$ \\
\hline Saha-UC & Sahal* 88 & Sahal*89 & Sahal*28 & Sahal*27 \\
\hline
\end{tabular}

\section{Discussion}

\section{Function of MHC genes}

Based on the genomic characterization of the MHC genes, as well as expression and diversity studies, we are now in the position to assign previously identified MHC alleles to loci and make informed deductions about the likely role of these genes in immune response.

Four Class II loci are described in this study, Saha-DAA, $D A B 1, D A B 2$ and $D A B 3$. Transcripts from the three $\beta$ chain genes have previously been described [18]. These loci likely encode functional antigen-presenting molecules based on homology to other members of the $D A$ gene family, which have been studied in a variety of marsupial species [reviewed in [25]]. No other Class II gene families have been identified in the devil, indicating that either the devil only has one functional Class II gene family or the other genes are too divergent from known marsupial Class II genes to be detected by the probes.

Amongst the five characterized Class I loci, we propose that Saha-UA,UB and $U C$ are functional Class Ia genes on the basis of three facts. First, their transcripts have been amplified from all tissue types examined so far, including blood, spleen, skin, liver, kidney and DFTD cells $[9,18]$. Second, genetic variation, though the level is not high, is present at these loci, particularly in the putative peptide-binding regions (Figure 9). Third, promoter elements in the 5' untranslated region are well conserved between these genes and the Class Ia genes in the opossum and the tammar wallaby [22], sharing $91.8 \%$ and $83.6 \%$ nucleotide identity respectively. Whether the single nucleotide variation in TATA box affects the expression level of Saha-UA remains uncertain. The number of Class Ia loci in the devil is comparable to those in the opossum (one) and the tammar wallaby (three).

Table 3 Comparison of Tasmanian devil MHC Class la genes.

\begin{tabular}{lllll}
\hline & & \multicolumn{3}{c}{ Sequence identity } \\
\cline { 3 - 5 } Gene & Length (bp) & Saha-UA & Saha-UB & Saha-UC \\
\hline Saha-UA & 2921 & - & $99.0 \%$ & $97.8 \%$ \\
Saha-UB & 2921 & $98.9 \%$ & - & $97.7 \%$ \\
Saha-UC & 2923 & $98.3 \%$ & $98.3 \%$ & - \\
\hline
\end{tabular}

Sequence identity in exons (shown below the diagonal) and introns (shown above the diagonal) are calculated separately
Table 4 Comparison of Tasmanian devil MHC DAB genes.

\begin{tabular}{lllll}
\hline Gene & \multicolumn{3}{c}{$\begin{array}{l}\text { Sequence } \\
\text { identity }\end{array}$} \\
\cline { 3 - 5 } & $\begin{array}{l}\text { Length } \\
\text { (bp) }\end{array}$ & $\begin{array}{l}\text { Saha- } \\
\text { DAB1 }\end{array}$ & Saha-DAB2 & $\begin{array}{l}\text { Saha- } \\
\text { DAB3 }\end{array}$ \\
\hline Saha- & 9448 & - & $95.7 \%$ & $61.9 \%$ \\
DAB1 & & & - & $62.8 \%$ \\
Saha- & 9261 & $96.9 \%$ & - & - \\
DAB2 & & $95.3 \%$ & $96.1 \%$ & \\
Saha- & 8558 & & & \\
DAB3 & & &
\end{tabular}

Sequence identity in exons (shown below the diagonal) and introns (shown above the diagonal) are calculated separately Sequence identity

Saha-UK has been found transcribed in the blood and spleen and is likely a Class Ib gene based on orthology with the Class Ib Modo-UK in the opossum and Maeu$U K$ in the tammar wallaby. It has been suggested that the high conservation of this gene over extended evolutionary periods indicates that it may serve a critical, marsupial-specific function [22].

Saha-UD, which has been found transcribed in the blood, spleen and DFTD cells, shows features of a Class Ib gene. This locus has significantly lower levels of polymorphism than Saha-UA,UB and $U C$, and its 5' regulatory elements are divergent. Within the $\alpha 1$ domain, Saha$U D$ alleles share extremely high sequence identity (> 97.7\%) and only one of the 15 putative peptide-binding amino acid residues is polymorphic (Figure 10). Elucidation of the functional role of Saha-UD in the devil remains to be determined.

Genomic characterization allowed us to assign previously characterized "group 1" alleles to Class Ia loci Saha- $U A, U B$ and $U C$, and "group 2" alleles to Saha- $U D$ ([19], Figure 5). The previous description of individuals containing only "group 1" or "group 2" alleles [19] was likely due to experimental artefact caused by nucleotide mismatches (two in Saha-UA, UB and $U C$; four in Saha$U D)$ within the PCR primer hybridisation sites. Here, we propose that Class Ia loci Saha-UB and $U C$ are likely present in all devils, whereas Saha-UA is lost in certain haplotypes. We suggest that in future studies new primers should be designed for Saha-UD and the three Class Ia genes separately to ensure high primer efficiency.

\section{Copy number variations (CNVs) in the MHC}

A genomic $\mathrm{CNV}$ is a duplication or deletion of a genomic segment larger than $1 \mathrm{~kb}$ in size [26]. In addition to single nucleotide polymorphisms, CNVs represent a major class of genetic variation and are widespread in the human genome $[27,28]$. Large-scale genome-wide disease association studies have revealed a number of CNVs in the HLA that are associated with Crohn's disease, rheumatoid arthritis and type 1 diabetes [26,29]. 


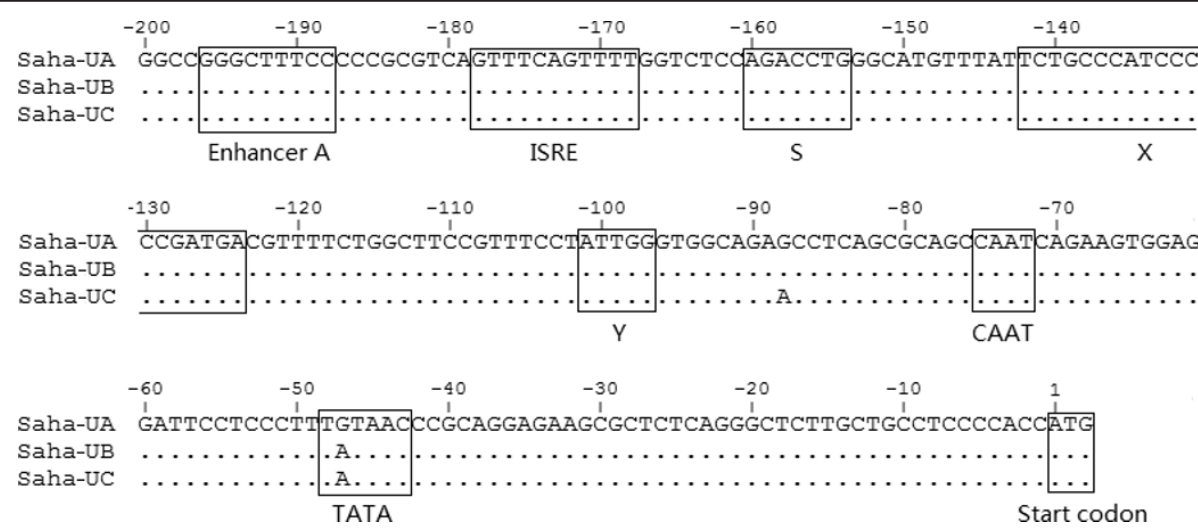

Figure 6 Putative promoter elements of Tasmanian devil MHC Class la genes. The boxed sequences indicate putative sites of an enhancer $A$, an interferon stimulated response element (ISRE), the S-X-Y motifs and the CAAT and TATA boxes.

When we first proposed the hypothesis of "Class I gene copy number variation" in the devil, we were referring to the concept of $\mathrm{CNV}$ in a narrow sense, namely variation in the number of Class I loci [19]. With the new findings from this study, it is necessary to expand the concept to take into account other CNVs of noncoding sequences lying within the devil MHC.

Three genomic copy number variants that intersperse with the MHC Class Ia genes were identified between Cedric's and Spirit's haplotypes. The one within Saha-UA is convincingly a deletion, while the other two are difficult to classify as either duplications or deletions. The loss of functional Class I genes due to CNVs is not specific to the devil. A case has been reported for a human haplotype where a $4 \mathrm{~kb}$ deletion turns $H L A-A$ into a pseudogene [30]. The mechanisms underlying the generation of these CNVs in the devil MHC are not clear, though a possible explanation may be implied from the presence of the putative LINE fragments in the affected regions encompassing the

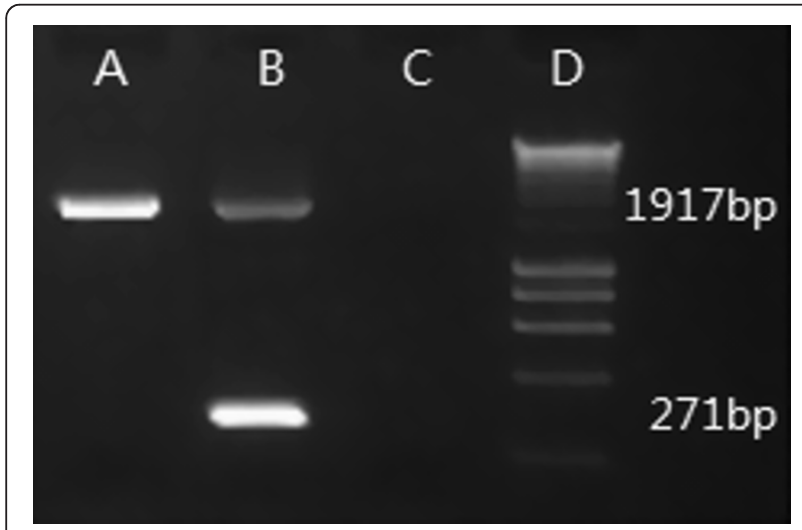

Figure $7 \mathrm{Gel}$ image showing two types of Tasmanian devil MHC Class I haplotypes. Gel lanes: A - Spirit's type with intact Class I gene Saha-UA; B - Cedric's type with a deletion in Saha-UA; C - negative control; D - HyperLadder I (Bioline). three CNVs and Saha-UA, UB and $U C$ genes (Figure 2). These retrotransposons may play a role in causing the $\mathrm{CNVs}$ as evidence has been found in primate genomes that LINEs are centrally involved in the generation of CNVs and can mediate deletions up to $18 \mathrm{~kb}$ in size [31,32].

The higher frequency of the Saha-UA deletion in the northwest may indicate that the eastern and western populations have been exposed to different selective pressures. It is tempting to continue to speculate that the deletion of Saha-UA, which was found in Cedric and occurs in high frequency in the northwest of Tasmania, may provide animals with some level of resilience to DFTD. This is consistent with the observation that the spread of DFTD is slowing down as the disease front reaches genetically disparate populations in the northwest and that the incidence of disease in these populations is much lower than in similar populations in the east [33]. This gene deletion may be advantageous for the following reasons. First, the loss of Saha-UA may increase the $\mathrm{MHC}$ antigenic dissimilarity between host and tumour, as a Saha-UA allele, SahaI*35, has been found to be transcribed in the tumour [19]. Second, the CNVs may alter the expression level of the adjacent $\mathrm{MHC}$ genes by affecting regulatory elements such as promoters and enhancers as well as inhibitory elements. In fact, it has been found that CNVs can even influence the expression of genes that are up to $1 \mathrm{Mb}$ away [34]. Here we have only looked at two devil MHC haplotypes and have only scratched the surface of the genetic variation that could be present amongst devil genomes. The role of this variation in the varied susceptibility/resistance of devils to DFTD needs to be further investigated.

Comparison with the opossum and tammar wallaby MHC Previous comparative studies revealed that the MHC of the opossum and the tammar wallaby exhibit distinct features in gene content and organisation $[21,35]$. 


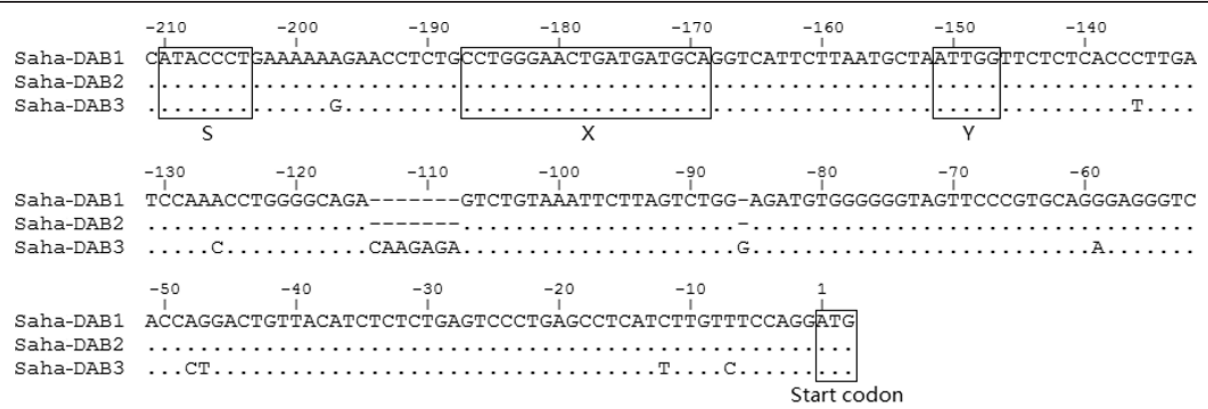

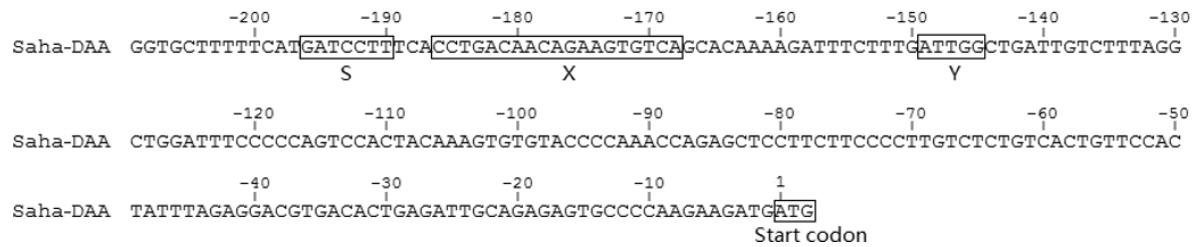

Figure 8 Upstream sequences of Tasmanian devil MHC Class II $\beta$ chain and $\alpha$ chain genes. The boxed sequences indicate putative sites of $S-X-Y$ motifs.

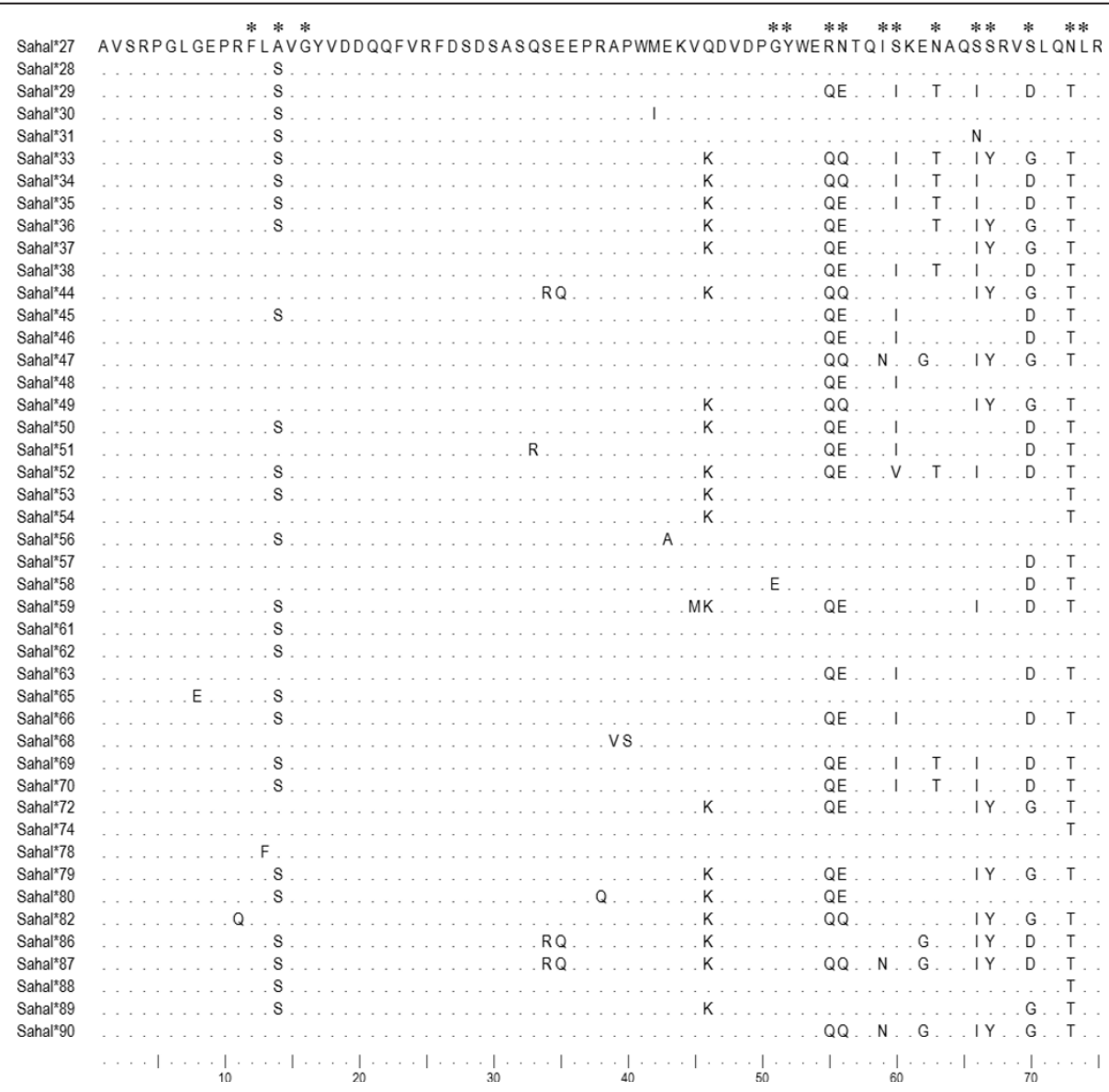

Figure 9 Amino acid alignment of partial $\alpha 1$ domain of Saha-UA, UB and $U C$ alleles. Asterisks indicate putative peptide-binding sites in a Class I molecule [48]. 


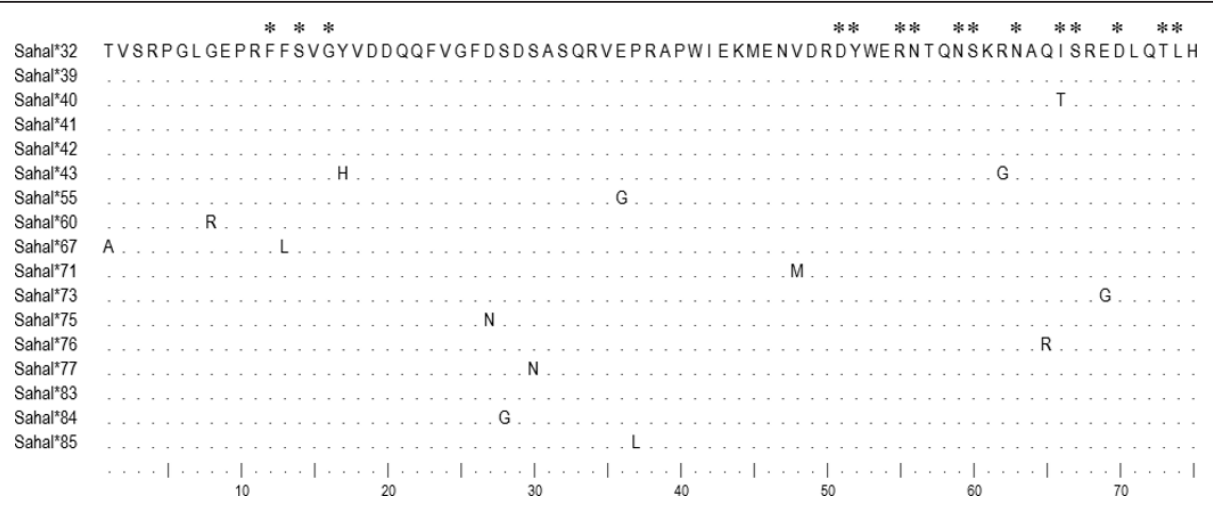

Figure 10 Amino acid alignment of partial $\alpha 1$ domain of Saha-UD alleles. Asterisks indicate putative peptide-binding sites in a Class I molecule [48].

Sequencing of Tasmanian devil MHC regions has provided us a better understanding of the marsupial MHC.

In the tammar wallaby, all Class Ia genes (UA,UB and $U C)$ are un-linked to the MHC region [22], whereas in the opossum the only confirmed Class Ia gene (UA1) is located within the MHC and close to antigen-processing genes ([21], Figure 4). The organisation of Class Ia genes in the devil is similar to that of the opossum, with $U A, U B$ and $U C$ adjacent to TAP1, TAP2, PSMB 9 and $P S M B 8$. This indicates that the dispersal of Class I genes across the genome in the tammar wallaby is not a common characteristic of the Australasian marsupial and has occurred after the divergence of devil and tammar wallaby's common ancestor at $\sim 66$ million years before present [36].

Four Class II gene families have been characterized in the opossum - DA, DB, DC and $D M$ [21]. DA, DB and $D M$ have also been identified in the tammar wallaby. The Class II genes have undergone large-scale expansion in the tammar wallaby, resulting in up to $10 D A B$ loci [35]. However, such an expansion of Class II genes is not seen in the devil, with devils having a single $D A A$ and three $D A B$ genes. On the contrary, the devil genome may have undergone gene deletions that have lead to loss of the $D B$ and $D C$ gene families.

In this study, we have focused on characterizing MHC Class Ia and II genes in the devil. Future work will involve characterization of the functional roles of the putative Class Ib genes, as well as genes involved in the antigen processing machinery.

\section{Conclusions}

Four Tasmanian devil genomic regions containing five MHC Class I genes and four MHC Class II genes were characterized by BAC based sequencing, which allowed us to assign previously sequenced MHC alleles to loci. We propose that Saha-UA, UB and $U C$ are Class Ia genes, Saha-UK is a transcribed Class Ib gene and the role of Saha-UD remains to be determined. The expression of Saha-UA,UB and $U C$ may be influenced by three genomic CNVs that are found within or adjacent to these loci. Future studies should focus on the role of CNVs in the MHC in susceptibility/resistance of devils to DFTD.

\section{Methods}

\section{Construction of bacterial artificial chromosome (BAC) libraries}

Two BAC libraries were produced. The first one, designated VMRC-49, was constructed from whole blood genomic DNA of Cedric (three-year-old male). The second library, designated VMRC-50, was constructed from genomic DNA extracted from the liver of Spirit (twoyear-old male). The genomes of both animals were recently sequenced [37]. The genome assembly was not able to provide an accurate picture of the MHC, which contains multiple closely related genes that have arisen from recent gene duplications. Therefore, a BAC clone sequencing project was required.

The BAC libraries were produced in the Genome Resource Center at the Benaroya Research Institute at Virginia Mason, Seattle, USA. Detailed procedures of library construction have been described previously $[38,39]$. The quality of the DNA was checked by running a pulsed field gel electrophoresis (PFGE) on a CHEF$\mathrm{DR}^{\circledR}$ III system (BioRad). The DNA was partially digested in an EcoRI/EcoRI-methylase competition reaction and size fractionated by analytical PFGE on a BioRad CHEF Mapper ${ }^{\circledR}$ XA system. DNA fragments from the appropriate size fraction were ligated into the CopyControl ${ }^{\mathrm{TM}}$ pCC1BAC ${ }^{\mathrm{TM}}$ vector from Epicentre Technologies and transformed into Invitrogen ElectroMAX ${ }^{\mathrm{TM}}$ DH10B ${ }^{\mathrm{TM}} \mathrm{T} 1$ Phage-Resistant $E$. coli cells. Transformants were arrayed into 384-well LB/chloramphenicol/glycerin microtiter plates (Genetix) using colony-picking robots (Norgren Systems) and subsequently gridded onto $22 \times 22 \mathrm{~cm}$ 
high-density nylon filters with a Total Array System (BioRobotics Ltd.). The average insert size was estimated to be $\sim 140 \mathrm{~kb}$. A total of 672 microtiter plates, which contain 258,048 BAC clones, and 14 high-density filters were produced for library VMRC-49. Assuming the size of the devil genome is similar to that of the opossum genome, which is around $3.6 \mathrm{~Gb}$, this library will represent $10 x$ coverage of the devil genome. For library VMRC-50, 432 plates containing 165,888 BAC clones and nine high-density filters were generated, estimated to represent $6.5 \mathrm{x}$ whole genome coverage.

\section{Characterization of MHC-positive BAC clones MHC probes}

MHC Class I and Class II $\beta$ chain probes for library screening were designed based on devil cDNA sequences [18]. Two Class I probes were used to screen both libraries. The first one was a $274 \mathrm{bp}$ fragment from Class I gene exon 2, which was amplified using PCR primers and conditions described previously [9]. The second Class I probe was a $191 \mathrm{bp}$ fragment from exon 4, amplified using forward primer 5' -CAGTGCCGGGCCCAGGACTTTTA -3 ' and reverse primer 5' -CCCTCGTGCTGAACTCGGCAGGT -3'. PCR was carried out on devil genomic DNA in a total volume of $25 \mu \mathrm{l}$, which contains 1x High Fidelity Buffer (Invitrogen) consisting of $60 \mathrm{mM}$ Tris- $\mathrm{HCl}(\mathrm{pH}$ 8.9) and $18 \mathrm{mM}\left(\mathrm{NH}_{4}\right)_{2} \mathrm{SO}_{4}, 2.5 \mathrm{mM} \mathrm{MgSO}{ }_{4}, 0.2 \mathrm{mM}$ each dNTP, $0.8 \mu \mathrm{M}$ each primer, and $1.5 \mathrm{U}$ of Platinum Taq DNA Polymerase High Fidelity (Invitrogen). PCR amplifications were performed on a BioRad MJ Mini Personal Thermal Cycler at the following conditions: $100^{\circ} \mathrm{C}$ hot lid; $94^{\circ} \mathrm{C}$ initial denaturation for $3 \mathrm{~min}$; 32 cycles of $94^{\circ} \mathrm{C}$ denaturation for $30 \mathrm{sec}, 60^{\circ} \mathrm{C}$ annealing for $30 \mathrm{sec}, 72^{\circ} \mathrm{C}$ extension for $30 \mathrm{sec}$; and $72^{\circ} \mathrm{C}$ final extension for $10 \mathrm{~min}$. Library VMRC-49 was also screened with two Class II probes for $\beta$ chain and $\alpha$ chain genes. The $\beta$ chain probe was a 237 bp fragment from devil $D A B$ gene exon 3, amplified with forward primer 5' - AGCCCGAGGTGACTGTGTATC -3' and reverse primer 5'- CGTGGC AGGTGTAGACATCTC -3'. PCR conditions were same as above. The $\alpha$ chain probe was designed from the exon 2 of a tammar wallaby DAA gene ([GenBank:CU464025], position 141572-141757) and amplified from tammar wallaby genomic DNA using the same PCR reagents and conditions as described above. All PCR amplicons were isolated by running a 1.8\% agarose gel using HyperLadder IV (Bioline) as size marker, and purified from the gel using MoBio UltraClean 15 DNA Purification Kit.

\section{Library screening}

Radioactively labelled probes were synthesized from approximately $50 \mathrm{ng}$ of PCR amplified MHC gene fragments with either $\left[\alpha-{ }^{32} \mathrm{P}\right] \mathrm{dCTP}$ or $\left[\alpha-{ }^{32} \mathrm{P}\right] \mathrm{dATP}$ (PerkinElmer) using Random Primed DNA Labeling Kit from Roche Applied Science. Unincorporated dNTPs were removed from the probe with Illustra ProbeQuant G-50 Micro Columns from GE Healthcare. Hybridisation of BAC filters with MHC probes was carried out overnight at $60^{\circ} \mathrm{C}$ in Amersham Rapid-hyb ${ }^{\mathrm{TM}}$ Buffer (GE Healthcare). Excess background and non-specific binding was minimized by washing the filters at $60^{\circ} \mathrm{C}$ with a series of buffers (2x SSC, $2 x$ SSC with $0.1 \%$ SDS, $1 x$ SSC with $0.1 \%$ SDS, and $0.5 x$ SSC with $0.1 \%$ SDS). Amersham Hyperfilm MP (GE Healthcare) was used to visualize positive clones after one to three days of exposure to the filters.

\section{$B A C$ clone sequencing}

BAC DNA of the positive clones was purified from $100 \mathrm{ml}$ $\mathrm{LB} /$ chloramphenicol bacterial culture using QIAGEN Large-Construct Kit. BACs containing unique MHC Class I or II genes were confirmed by direct end sequencing of BAC DNA with MHC primers, using standard sequencing service at the Australian Genome Research Facility Ltd. Fingerprinting analysis and complete sequencing of MHCpositive BAC clones was conducted at the Wellcome Trust Sanger Institute, Cambridge, UK. Traditional Sanger sequencing method was employed to ensure high assembly accuracy of paralogous MHC genes.

\section{$B A C$ sequence annotation}

BAC sequences were aligned with human genomic and transcript sequences, non-human reference RNA sequences, and known or predicted opossum and tammar wallaby transcripts using web-based BLAST programs [40]. Genes were annotated manually based on the best BLAST hits and in accordance with the recommendations of the Human and vertebrate analysis and annotation guidelines [41]. Overlapping BAC sequences were identified and aligned using BLASTN and ClustalW programs [42]. A wallaby LINE-1 segment [GenBank:DQ275763] was used to search for putative LINE segments.

\section{Fluorescent in situ hybridisation (FISH)}

BAC clones containing MHC Class I or II genes were physically mapped to a male devil karyotype following the protocol described previously by Alsop and colleagues [43]. Approximately $1 \mathrm{mg}$ of BAC DNA was used to produce probes that were labelled by nick translation with either SpectrumOrange dUTP or SpectrumGreen dUTP (Abbott Molecular Inc.). Labelled probes were hybridised overnight to devil chromosomes, which were denatured for $1 \mathrm{~min} 40 \mathrm{sec}$. Slides were washed once at $60^{\circ} \mathrm{C}$ in $0.4 \mathrm{x}$ SSC with $0.3 \%$ Tween 20 for $2 \mathrm{~min}$ and then once in $2 \mathrm{x}$ SSC with $0.1 \%$ Tween 20 for $30 \mathrm{sec}$ at room temperature. Chromosomes were counterstained in DAPI and mounted in VECTASHIELD ${ }^{\circledR}$ Mounting Medium from Vector Laboratories Inc. A Zeiss Axioplan2 epifluorescence microscope was used to visualize the fluorescent signals. Images of DAPI stained metaphase chromosomes and fluorescent signals were captured using a SPOT RT Monochrome CCD charge-coupled 
device camera (Diagnostic Instruments Inc.) and merged using IP Lab imaging software (Scanalytics Inc.).

\section{Sequencing and analysis of MHC class I alleles}

To test the Class I gene number variation hypothesis, it was necessary to ensure that all Class I loci in both Cedric and Spirit were characterized. To do this, we isolated and sequenced all Class I alleles from both individuals and assigned them to genes. We amplified exon 2 of the Class I genes from genomic DNA using protocols developed by Siddle and colleagues [9] with modifications in the reverse primer sequence (5'- CTCGCTCTGGTTGTAGTAGCC 3 '). Two independent PCRs were performed for each individual. The PCR amplicons were gel-purified and cloned in a pGEM-T Easy Vector (Promega)/JM109 High Efficiency Competent Cells (Promega) cloning system. 32 positive clones were picked for each individual and plasmids were extracted using QIAGEN DirectPrep 96 MiniPrep Kit on a QIAvac Multiwell vacuum manifold (QIAGEN). Plasmids were sequenced with T7 primer at the Australian Genome Research Facility, Sydney, Australia. Sequences were quality-checked using Sequencher 4.1.4 (Gene Codes) and aligned with previous identified devil Class I alleles [19] in BioEdit 7.0.9 [44]. To minimize errors yielded during PCR, cloning and sequencing, new sequence variants were determined to be real alleles only if they were found in more than one PCR amplification. Alleles were assigned to genomic loci based on nucleotide sequence similarity. Evolutionary relationships of devil Class I sequences were analysed by constructing a Neighbour-Joining phylogenetic tree with MEGA5 [45].

\section{PCR primer design}

Two pairs of new PCR primers were designed using program Oligo 6.7 (Molecular Biology Insights). One pair (forward 5'- TTTGCAAGCTTCCATGTCTCT -3', reverse 5'-CACTTGTGCTTGGAGTTCAGA -3') amplified partial exon 2 to exon 3 of the Class I gene Saha-UK from devil cDNA. The other pair was designed to detect a deletion in Class I gene Saha-UA, with the forward primer 5'TGTCCCCCCCTCCGTCTCAG -3'binding to the end of intron 1 and the reverse 5'- CAGGAGAGGAGACCACACTAAGAT -3'binding to the end of intron 5. In about $5 \%$ of samples, this set of primers was found to work less efficiently, which could be due to nucleotide variations in primer binding sites. PCR conditions for both primer sets were the same as the one provided above. PCR products were sequenced to confirm correct amplification sites.

\section{Additional material}

Additional file 1: Figure S1 FISH image showing genomic locations of BAC clone C12G5 and C491111. The individual used in this slide has a balanced translocation between Chr.1 and Chr.3.
Additional file 2: Figure S2 Alignment of sequences used to generate Figure 5, including all Tasmanian devil Class I alleles identified so far.

\section{Acknowledgements}

This work was funded by an ARC Future Fellowship to KB (FT0992212), the Eric Guiler fund and the Tasmanian Department of Primary Industries, Parks, Water and the Environment. YC was supported by an Endeavour International Postgraduate Research Scholarship, KM by an Australian Postgraduate Award and an ARC Linkage Grant. We thank Carol Churcher, Lucy Matthews, David Willey, Claire Murnane, Nicola Corton, Jennifer Harrow and Charlie Steward at the Wellcome Trust Sanger Institute, Cambridge for mapping, shotgun library making, capillary sequencing and finishing the BAC clones, Elizabeth Murchison for establishing the collaboration with the Sanger Institute, and the Save the Tasmanian Devil Program team and Rodrigo Hamede and Shelly Lachish at the University of Tasmania for sample collection collection and Ke-jun Wei from ANU for DNA extraction.

\section{Author details}

${ }^{1}$ Faculty of Veterinary Science, University of Sydney, Sydney, NSW, Australia. ${ }^{2}$ Genome Resource Center, Benaroya Research Institute at Virginia Mason, Seattle, WA, USA. ${ }^{3}$ Department of Primary Industries, Parks, Water and Environment, Prospect, TAS, Australia. ${ }^{4}$ Department of Pathology, University of Cambridge, Cambridge, UK. ${ }^{5}$ Research School of Biology, The Australian National University, Canberra, ACT, Australia. ${ }^{6}$ School of Zoology, University of Tasmania, Hobart, TAS, Australia. ${ }^{7}$ Faculty of Veterinary Science, University of Sydney, RMC Gunn B19, Sydney, NSW 2006, Australia.

\section{Authors' contributions}

YC, AS, KM, RT constructed the BAC libraries under the supervision of CTA. YC carried out all laboratory experiments, analysed the data and wrote the first draft of the manuscript. HS provided supervision in the lab. JD supervised FISH experiments. MJ provided devil samples. KB conceived and designed the project and revised the manuscript together with YC. All authors read drafts of the manuscript.

Received: 1 August 2011 Accepted: 12 March 2012

Published: 12 March 2012

\section{References}

1. Jones ME: Large marsupial carnivores. In The Encyclopedia of Mammals. Edited by: Macdonald DW. Oxford, UK: Oxford University Press; 2001:814-817.

2. Brown OJF: Tasmanian devil (Sarcophilus harrisi) extinction on the Australian mainland in the mid-Holocene: multicausality and ENSO intensification. Alcheringa: An Australasian Journal of Palaeontology 2006, 30:49-57.

3. Hawkins CE, Baars C, Hesterman H, Hocking GJ, Jones ME, Lazenby B, Mann D, Mooney N, Pemberton D, Pyecroft S, et al: Emerging disease and population decline of an island endemic, the Tasmanian devil Sarcophilus harrisi. Biological Conservation 2006, 131:307-324.

4. Jones ME, Paetkau D, Geffen E, Moritz C: Genetic diversity and population structure of Tasmanian devils, the largest marsupial carnivore. Molecular Ecology 2004, 13:2197-2209.

5. Hamede R, McCallum H, Jones ME: Seasonal, demographic and densityrelated patterns of contact between Tasmanian devils: Implications for transmission of Devil Facial Tumour Disease. Austral Ecology 2008, 33:614-622.

6. Pearse AM, Swift K: Allograft theory: transmission of devil facial-tumour disease. Nature 2006, 439:549.

7. Murchison EP, Tovar C, Hsu A, Bender HS, Kheradpour P, Rebbeck CA, Obendorf D, Conlan C, Bahlo M, Blizzard CA, et al: The Tasmanian Devil Transcriptome Reveals Schwann Cell Origins of a Clonally Transmissible Cancer. Science 2010, 327:84-87.

8. Woods G, Kreiss A, Belov K, Siddle H, Obendorf D, Muller H: The Immune Response of the Tasmanian Devil (Sarcophilus harrisi) and Devil Facial Tumour Disease. EcoHealth 2007, 4:338-345.

9. Siddle HV, Kreiss A, Eldridge MDB, Noonan E, Clarke CJ, Pyecroft S, Woods GM, Belov K: Transmission of a fatal clonal tumor by biting occurs 
due to depleted MHC diversity in a threatened carnivorous marsupial. Proceedings of the National Academy of Sciences 2007, 104:16221-16226.

10. Janeway CA, Travers P, Walport M, Shlomchik M: Immunobiology: the immune system in health and disease New York, USA: Garland Publishing: 2001.

11. Parham P, Strominger JL: Histocompatibility Antigens Structure and Function. In Receptors and Recognition Series B. Volume 14. New York: Chapman and Hall; 1982.

12. Cresswell P, Ackerman AL, Giodini A, Peaper DR, Wearsch PA: Mechanisms of MHC class I-restricted antigen processing and cross-presentation. Immunological Reviews 2005, 207:145-157.

13. Stroynowski I, Lindahl KF: Antigen presentation by non-classical class I molecules. Current Opinion in Immunology 1994, 6:38-44.

14. Pieters J: MHC class II-restricted antigen processing and presentation. Advances in Immunology 2000, 75:159-208.

15. Nei M, Gu X, Sitnikova T: Evolution by the birth-and-death process in multigene families of the vertebrate immune system. Proceedings of the National Academy of Sciences 1997, 94:7799-7806.

16. Trowsdale J, Parham P: Mini-review: Defense strategies and immunityrelated genes. European Journal of Immunology 2004, 34:7-17.

17. Hughes AL: Adaptive Evolution of Genes and Genomes New York, USA: Oxford University Press; 1999.

18. Siddle HV, Sanderson C, Belov K: Characterization of major histocompatibility complex class I and class II genes from the Tasmanian devil (Sarcophilus harrisi). Immunogenetics 2007, 59:753-760.

19. Siddle HV, Marzec J, Cheng $Y$, Jones M, Belov K: MHC gene copy number variation in Tasmanian devils: implications for the spread of a contagious cancer. Proceedings of the Royal Society B 2010, 277:2001-2006.

20. Klein J, Bontrop RE, Dawkins RL, Erlich HA, Gyllensten UB, Heise ER, Jones PP, Parham P, Wakeland EK, Watkins DI: Nomenclature for the major histocompatibility complexes of different species: a proposal. Immunogenetics 1990, 31:217-219.

21. Belov K, Deakin JE, Papenfuss AT, Baker ML, Melman SD, Siddle HV, Gouin N, Goode DL, Sargeant TJ, Robinson MD, et al: Reconstructing an Ancestral Mammalian Immune Supercomplex from a Marsupial Major Histocompatibility Complex. PLoS Biology 2006, 4:e46.

22. Siddle HV, Deakin JE, Coggill P, Hart E, Cheng Y, Wong ESW, Harrow J, Beck S, Belov K: MHC-linked and un-linked class I genes in the wallaby. BMC Genomics 2009, 10:310.

23. Baker ML, Melman SD, Huntley J, Miller RD: Evolution of the opossum major histocompatibility complex: evidence for diverse alternative splice patterns and low polymorphism among class I genes. Immunology 2009, 128:e418-e431.

24. Vallejo AN, Pease LR: Evolution of class I promoter sequences: relationship to function and diversity. Immunological Reviews 1995 143:249-262

25. Cheng Y, Siddle HV, Belov K: The Marsupial Major Histocompatibility Complex. In Marsupial Genetics and Genomics. Edited by: Deakin JE, Waters PD, Graves JAM. Dordrecht, Springer; 2010:.

26. Grayson BL, Smith ME, Thomas JW, Wang L, Dexheimer P, Jeffrey J, Fain PR, Nanduri P, Eisenbarth GS, Aune TM: Genome-Wide Analysis of Copy Number Variation in Type 1 Diabetes. PLOS ONE 2010, 5:e15393.

27. lafrate AJ, Feuk L, Rivera MN, Listewnik ML, Donahoe PK, Qi Y, Scherer SW, Lee C: Detection of large-scale variation in the human genome. Nature Genetics 2004, 36:949-951.

28. Sebat J, Lakshmi B, Troge J, Alexander J, Young J, Lundin P, Månér S, Massa H, Walker M, Chi M, et al: Large-Scale Copy Number Polymorphism in the Human Genome. Science 2004, 305:525-528.

29. The Wellcome Trust Case Control Consortium: Genome-wide association study of CNVs in 16,000 cases of eight common diseases and 3,000 shared controls. Nature 2010, 464:713-720.

30. Voorter CEM, Lauterbach N, Tilanus MGJ: Inactivation of a functional HLAA gene: A 4-kb deletion turns HLA-A*24 into a pseudogene. Human Immunology 2010, 71:1197-1202.

31. Han K, Sen SK, Wang J, Callinan PA, Lee J, Cordaux R, Liang P, Batzer MA: Genomic rearrangements by LINE-1 insertion-mediated deletion in the human and chimpanzee lineages. Nucleic Acids Research 2005, 33:4040-4052

32. Han K, Lee J, Meyer TJ, Remedios P, Goodwin L, Batzer MA: L1 recombination-associated deletions generate human genomic variation. Proceedings of the National Academy of Sciences 2008, 105:19366-19371.
33. Hamede R, Lachish S, Belov K, Woods G, Kreiss A, Pearse A-M, Lazenby B, Jones M, McCallum H: Reduced Effect of Tasmanian Devil Facial Tumor Disease at the Disease Front. Conservation Biology 2011, early view DOI:10.1111/j.1523-1739.2011.01747.x.

34. Stranger BE, Forrest MS, Dunning M, Ingle CE, Beazley C, Thorne N, Redon R, Bird CP, de Grassi A, Lee C, et al: Relative Impact of Nucleotide and Copy Number Variation on Gene Expression Phenotypes. Science 2007, 315:848-853.

35. Siddle H, Deakin J, Coggill P, Wilming L, Harrow J, Kaufman J, Beck S, Belov K: The tammar wallaby major histocompatibility complex shows evidence of past genomic instability. BMC Genomics 2011, 12:421.

36. Kirsch JAW, Lapointe F-J, Springer MS: DNA-hybridisation Studies of Marsupials and their Implications for Metatherian Classification. Australian Journal of Zoology 1997, 45:211-280.

37. Miller W, Hayes VM, Ratan A, Petersen DC, Wittekindt NE, Miller J, Walenz B, Knight J, Qi J, Zhao F, et al: Genetic diversity and population structure of the endangered marsupial Sarcophilus harrisii (Tasmanian devil). Proceedings of the National Academy of Sciences 2011, published ahead of print June 27, 2011, doi:2010.1073/pnas.1102838108.

38. Amemiya CT, Ota T, Litman GW: Construction of P1 artificial chromosome (PAC) libraries from lower vertebrates. In Nonmammalian Genomic Analyses: A Practical Guide. Edited by: Birren B, Lai E. San Diego: Academic Press; 1996:223-256.

39. Oosegawa K, Woon PY, Zhao B, Frengen E, Tateno M, Catanese JJ, de Jong PJ: An improved approach for construction of bacterial artificial chromosome libraries. Genomics 1998, 52:1-8.

40. Altschul SF, Gish W, Miller W, Myers EW, Lipman DJ: Basic local alignment search tool. Journal of Molecular Biology 1990, 215:403-410.

41. Human and Vertebrate Analysis and Annotation Guidelines. [http://www. sanger.ac.uk/research/projects/vertebrategenome/havana/assets/guidelines. pdf].

42. Thompson JD, Higgins DG, Gibson TJ: CLUSTAL W: improving the sensitivity of progressive multiple sequence alignment through sequence weighting, position specific gap penalties and weight matrix choice. Nucleic Acids Research 1994, 22:4673-4680.

43. Alsop AE, Miethke P, Rofe R, Koina E, Sankovic N, Deakin JE, Haines $H$, Rapkins RW, Graves JAM: Characterizing the chromosomes of the Australian model marsupial Macropus eugeni (tammar wallaby). Chromosome Research 2005, 13:627-636.

44. Hall T: Bioedit: a user friendly biological sequence alignment editor and analysis program for windows 95/98/NT. Nucleic Acids Symposium Series 1999, 41:95-98.

45. Tamura K, Dudley J, Nei M, Kumar S: MEGA4: Molecular Evolutionary Genetics Analysis (MEGA) software version 4.0. Molecular Biology and Evolution 2007, 10.1093/molbev/msm1092

46. Saitou N, Nei M: The neighbor-joining method: A new method for reconstructing phylogenetic trees. Molecular Biology and Evolution 1987, 4:406-425

47. Felsenstein J: Confidence limits on phylogenies: An approach using the bootstrap. Evolution 1985, 39:783-791.

48. Bjorkman PJ, Parham P: Structure, function, and diversity of class I major histocompatibility complex molecules. Annual Review of Biochemistry 1990, 59:253-288.

doi:10.1186/1471-2164-13-87

Cite this article as: Cheng et al: Antigen-presenting genes and genomic copy number variations in the Tasmanian devil MHC. BMC Genomics 2012 13:87. 